\title{
Implikasi Pendidikan dari Al-Quran Surat Al-Kahfi Ayat 10 -16 tentang Kisah Ketangguhan Iman Pemuda Ashabul Kahfi terhadap Upaya Menanamkan Akidah
}

\author{
Muhammad Dwieky Cahyadien*, Aep Saepudin \\ Prodi Pendidikan Agama Islam, Fakultas Tarbiyah dan Keguruan, \\ Universitas Islam Bandung, Indonesia. \\ *2009dwieki@gmail.com, aepsaepudinunisba@gmail.com
}

\begin{abstract}
This verse tells the obligation to maintain the creed, in it it says that when there is a big slander damage their creed, it is implied that as a Muslim must maintain their creed. The formulation of the problem is : (1) What is the content of Q.S Al-Kahf verses 10-16 in the opinion of the commentators? (2) What is the essence of Q.S Al-Kahf verses 10-16? (3) What is the theory of faith education according to experts? (4) What are the implications listed in Q.S Al-Kahfi verses 10-16 about the story of the tough faith of the youth of Ashabul Kahfi towards efforts to instill faith education? This study use descriptive-analytical method of collection, namely library research by examining in depth various interpretations and books related to the subject matter of the research. From this research, it is found the contents of QS Al-Kahf verses 10-16 are that muslim must be able to maintain their faith, because when muslim maintain it according to the guidance of the Prophet Muhammad Saw, Allah's broad help will come down. According to education experts, efforts to instill faith education, first, opening life with the sentence syahadat, introducing halal and haram, ordering him to worship, educating to love the family and the Qur'an. The implication is that a Muslim must be given an understanding that it is necessary to protect his faith, because this is an order from Allah SWT. Educator must try to instill faith by making cooperation between mosque, school, and home.
\end{abstract}

Keywords: Education Creed, Educator, Juvenilition, Al-Kahfi 10-16.

\begin{abstract}
Abstrak. Ayat ini menerangkan tentang kewajiban dalam menjaga akidah, didalamnya dikatakan bahwa ketika terjadinya fitnah besar di negaranya yang dapat merusak akidahnya maka tersirat bahwa sebagai muslim harus menjaga akidah Islamnya. Munculah rumusan masalah yaitu: (1) Bagaimana isi kandungan Q.S Al-Kahfi ayat 10-16 menurut pendapat para mufasir? (2) Bagaimana esensi dari Q.S Al-Kahfi ayat 10-16? (3) Bagaimana teori pendidikan keimanan menurut para ahli? (4) Apa implikasi yang tercantum dalam Q.S Al-Kahfi ayat 10-16 tentang kisah ketangguhan iman pemuda ashabul kahfi terhadap upaya menanamkan pendidikan akidah?. Penelitian ini menggunakan metode deskriptif-analitis teknik pengumpulan yaitu kepustakaan (library reasearch) dengan mengkaji secara mendalam berbagai tafsir dan buku yang berhubungan dengan pokok masalah penelitian. Dari penelitian ayat ini diperoleh isi kandungan QS Al-Kahfi ayat 10-16 yaitu pemuda harus dapat menjaga akidahnya dari hal-hal yang dapat merusak keimanannya, karena disaat pemuda berikhtiar dalam menjaganya sesuai tuntunan Nabi Muhammad Saw maka pertolongan Allah Swt yang luas akan turun. Menurut para ahli pendidikan ada upaya menanamkan pendidikan akidah yaitu dengan Membuka kehidupan dengan kalimat Laa Ilaaha Illalaah, Mengenalkan hukum-hukum halal dan haram, Menyuruhnya untuk beribadah ketika telah memasuki usia tujuh tahun, Mendidiknya untuk mencintai rasul, keluarganya, dan membaca Al-Qur'an. Implikasi yang terdapat dalam Al-Qur'an Surat Al Kahfi ayat 10-16 adalah Seorang muslim harus diberi pemahaman bahwa perlu menjaga akidahnya dari segala hal yang dapat merusak akidahnya, karena hal tersebut merupakan perintah Allah Swt. dan supaya terhindarnya dari pemikiran yang sesat atau menyimpang. Seorang pendidik hendaknya berupaya menanamkan akidah dengan membuat kerja sama antara lingkungan masjid, sekolah, dan rumah.
\end{abstract}

Kata Kunci: Pendidikan Akidah, Pendidik, Pemuda, Al-Kahfi 10-16. 


\section{A. Pendahuluan}

Islam dibangun dengan 3 pondasi yaitu akidah, syari'at, dan akhlak. Ketiga pondasi tersebut merupakan satu kesatuan yang tidak dapat dipisahkan. Sehingga penanaman ketiga pondasi Islam tersebut harus dimulai sejak dini dan hal tersebut merupakan tanggung jawab dari orang tua, sebagaimana sabda Nabi Muhammad Saw., yaitu :

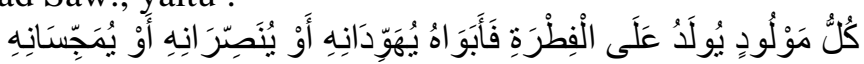

Artinya : "Setiap anak dilahirkan dalam keadaan fithrah. Kemudian kedua orang tuanyalah yang akan menjadikan anak itu menjadi Yahudi, Nashrani atau Majusi."

Dari dalil tersebut disaat orang tua tidak memahami akan pentingnya penanaman akidah sejak dini maka akan terjadi sebagaimana fenomena remaja saat ini, yaitu kurangnya menggantungkan diri kepada Allah Subhanahu wa ta'ala, bahkan hal tersebut berakibat timbulnya perilaku tercela, seperti viralnya sebuah video yang memperlihatkan siswi-siswi SMA berpesta miras, adapun aksi yang viral lainnya yaitu kenakalan remaja di media sosial berupa atraksi motor di makam (Kompas.com, 2019). Hal ini menunjukan bahwa pemuda saat ini memiliki pemahaman akidah yang kurang, bahkan perilaku yang timbul karena memiliki masalah kehidupan ataupun semacamnya, malah berlari menuju perilaku yang dapat menimbulkan dosa ketimbang berdo'a atau berserah diri kepada Allah Subhanahu wa ta'ala.

Dari fenomena tersebut, bahwa penanaman akidah di dalam keluarga pada zaman ini masih dinilai kurang tertanam pada diri muslim. Banyak dari orang tua yang masih belum paham mengenai pentingnya penanaman akidah pada anak, yang nantinya akan berpengaruh pada perilaku dari anak itu sendiri, sehingga perlu adanya penanaman akidah dengan cara yang tepat oleh orang tua. Karena pada dasarnya manusia memiliki fitrahnya yaitu bertauhid atau beriman kepada yang Maha Esa, sebagaimana Firman Allah Subhanahu wa ta'ala didalam surat Ar-Rum ayat 30 dan Al-Araf ayat 172

Pemuda ashabul kahfi menghadirkan buah dari keimanannya yang berupa cinta dan takut kepada Allah, maka disaat mereka dalam keadaan apapun akan menggantungkan dirinya kepada Allah Subhanahu wa ta'ala, seperti halnya yang tercantum dalam Q.S. Al-Kahfi ayat 10-16. Bahwasannya disaat mereka terbilang sebagai pemuda dan terdesak oleh fenomena yang terjadi di negaranya pada waktu itu, mereka bergantung dan meminta pertolongan kepada Allah Subhanahu wa ta'ala, yang hal ini merupakan indikator dari iman yang tangguh khususnya bagi seorang remaja.

Menurut Harold Alberty (1967:86), remaja adalah masa peralihan antara masa anak dan masa dewasa yang berlangsung 11-13 tahun sampai 18-20 tahun menurut umur kalender kelahiran seseorang. Terjadinya permasalahan pada remaja zaman sekarang yang berumur 1113 tahun sampai 18-20 tahun yaitu seperti, melakukan mabuk, berkelahi, berhubungan intim dengan yang bukan muhrimnya, dan lain sebagainya. Dari penjelasan tersebut maka harus adanya upaya pencegahan dengan pendidikan akidah dari orang tua, karena perilaku-perilaku penyimpangan dari remaja ini mesti di hentikan, salah satunya dengan upaya pendidikan akidah itu sendiri yang menjadi dasar dari perilaku manusia khususnya remaja.

Mengutip pernyataan dari Abdullah Nashih 'Ulwan (2020 :112) dari kitabnya yang berjudul tarbiyatul aulad fil islam, bahwasannya ada 4 tahap tanggung jawab paling utama bagi pendidik termasuk orang tua dalam pendidikan iman anak, yaitu :

1. Membuka kehidupan anak dengan kalimat Tauhid la ilaha illallah,

2. Mengajarkannya masalah halal dan haram setelah ia berakal,

3. Memerintahkannya untuk beribadah saat umurnya tujuh tahun,

4. Mendidiknya untuk cinta kepada nabi, keluarganya, dan cinta membaca Al-Qur'an.

Keseluruhan dari pemahaman akan pendidikan iman ini berlandaskan pada wasiat Rasulullah Saw. dan petunjuknya menuntun anak memahami dasar-dasar iman, rukun-rukun Islam, dan hukum-hukum syariat.

Maka dari uraian diatas bahwasannya pendidikan akidah merupakan proses pengubahan sikap dan tata laku sebagai upaya pembentukan atau penanaman keyakinan terhadap seseorang atau kelompok. Hal ini selaras dengan pernyataan menurut Munardji (2004:5) bahwa pendidikan adalah suatu proses penanaman sesuatu kedalam diri manusia. Pendidikan adalah bagian yang tidak dapat terpisahkan dari kehidupan manusia, salah satu yang penting dan 
menjadi utama yaitu pendidikan akidah yang bersumber dari Al-Qur'an dan Hadits.

Teori pendidikan akidah menurut Abdullah Nasih 'Ulwan dalam kitabnya tarbiyatul aulad fil islam, bahwasannya diantara faktor efektif dalam pembentukan kepribadian intelektual anak, rohani, dan fisiknya adalah mengadakan kerjasama yang baik antara rumah, sekolah, dan masjid. Sebagaimana yang kita ketahui bahwa rumah memliki peranan tanggung jawab nomor satu dalam mendidik anak. Maka dari itu termasuk dosa besar bagi siapa saja yang mengabaikan hak anak.

Dari uraian di atas dapat disimpulkan bahwa keimanan seseorang terkadang naik dan turun, serta adanya perbedaan kualitas iman antara mukmin yang satu dengan mukmin yang lainnya. Sehingga para pemuda Ashabul Kahfi memiliki iman yang sangat tangguh, mereka rela meninggalkan negerinya bukan karena khawatir akan penguasanya, tetapi mereka takut kehilangan keimanannya kepada Allah subhanahu wa ta'ala, maka karena hal tersebut Allah pun memuliakan mereka dengan menambahkan hidayah-Nya bagi mereka.

Seorang remaja juga dituntut harus mampu mengendalikan tingkah lakunya. Sudah sewajarnya bagi orang tua yang cinta agama dan cinta terhadap anaknya, berpikir untuk mewariskan nilai-nilai yang luhur ini kepada pemuda generasi yang akan datang.

\section{B. Metodologi Penelitian \\ Pendekatan dan Metode Penelitian}

1. Metode Penelitian

Penelitian ini menggunakan metode deskriptif-analitis, dalam metode ini berfokus kepada suatu pemahaman yang menjadi masalah secara mendalam. Sehingga permasalahan yang diambil dapat ditemukan jawaban atas permasalahan tersebut.

2. Pendekatan Penelitian

Penelitian ini menggunakan pendekatan penelitian kualitatif. Mencari data mengenai halhal atau variabel berupa buku, jurnal, kitab terjemahan tafsir, dan lain sebagainya. Melalui pendekatan penelitian kualitatif, diperoleh data yang berkaitan dengan penelitian berdasarkan konsep-konsep kerangka penulisan yang telah dipersiapkan sebelumnya.

\section{Teknik pengumpulan data}

Teknik pengumpulan data dalam penulisan skripsi ini adalah dengan menggunakan teknik library research. Mencari data mengenai hal-hal atau variabel berupa buku, jurnal, kitab terjemahan tafsir, dan lain sebagainya. Melalui teknik library research, diperoleh data yang berkaitan dengan penelitian berdasarkan konsep-konsep kerangka penulisan yang telah dipersiapkan sebelumnya.

\section{Hasil Penelitian dan Pembahasan}

Upaya menanamkan pendidikan akidah dari kisah ketangguhan iman pemuda ashabul kahfi.

1. Seorang pemuda harus kuat dalam menjaga keimanannya dari fitnah yang dapat merusak akidah.

Keimanan seorang pemuda akan dipandang kuat ketika mereka dalam keadaan susah maupun senang akan senantiasa bergantung dan berdo'a kepada Allah Swt. sebagaimana pemuda Ashhabul kahfi yang Ketika dilanda fitnah yang dapat merusak akidah Islam oleh penguasa di negaranya, maka mereka berdo'a kepada Allah Swt. yaitu dengan do'a :

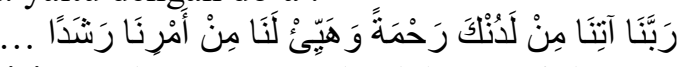

“... Berikanlah rahmat kepada Kami dari sisi-Mu dan sempurnakanlah petunjuk yang lurus bagi kami dalam urusan Kami.” (Q.S. Al-Kahfi [18]: 10-12)

Dari para mufassir menjelaskan bahwa Allah Swt seakan-akan berfirman secara tersirat kepada Rasulullah Saw, "Ingatkanlah, wahai rasul, ketika para pemuda itu pergi ke gua, guna menyelamatkan agama mereka dari fitnah kaum mereka". Lalu Allah tidurkan mereka dengan waktu yang Panjang sehingga terhindar dari fitnah yang merusak akidah mereka sampai mereka di bangunkan kembali 
Menurut Mohammad Daud Ali (2013 : 199), Akidah berasal dari Bahasa Arab yaitu secara etimologi artinya adalah ikatan, sangkutan. Disebut demikian karena ia mengikat dan menjadi sangkutan atau gantungan segala sesuatu. Dalam pengertian teknis artinya adalah iman atau keyakinan. Akidah Islam (aqidah Islamiyah), karena itu, dikaitkan dengan rukun iman yang menjadi asas dari seluruh ajaran Islam.

Dari uraian diatas, maka akidah yang secara teknis disebut iman atau keyakinan itu, para pemuda harus dapat menjaganya dari fitnah, sebagaimana pemuda Ashhabul Kahfi yang dikisahkan dalam Al-Qur'an surat Al-Kahfi ayat 10-16. keimanan pemuda harus dijaga karena mereka sedang dalam fase pubertas yang dimana sikap perilaku mereka tidak stabil. Karena Akidah Islam pada seseorang bersifat mengikat akan ajaran Islam, maka hal tersebut akan mempengaruhi terhadap sikap perilaku mereka yang cenderung tidak stabil kepada perilaku kebaikan sebagaimana ajaran Islam.

Hal tersebut dapat terjadi sebagaimana pendapat menurut Jalaludin (2016:65) bahwa sejalan dengan perkembangan jasmani dan rohani pemuda, maka agama pada para remaja itu turut dipengaruhi perkembangannya, maksudnya penghayatan para remaja terhadap ajaran agama dan tindak keagamaan yang tampak pada para remaja banyak berkaitan dengan faktor perkembangan tersebut.

Dari hal tersebut, maka seorang pemuda harus terbiasa dan dibiasakan berada dalam koridor keagamaan, supaya mereka yang sedang mengalami pada fase perkembangan dapat stabil dalam berperilaku karena terjaga akidah mereka secara yang tidak langsung mengontrol perilaku mereka.

\section{Allah akan memberikan pertolongan dalam bentuk apapun yang tidak pernah terduga kepada seorang yang imannya teguh kepada Allah.}

Seorang pemuda dalam menjaga akidahnya perlu adanya ikhtiar, diantaranya adalah do'a dan usaha. Ketika kedua hal tersebut dilakukan Allah akan memberikan pertolongan kepada hambanya yang ingin menjaga akidahnya dari hal yang dapat merusak akidahnya, salah satunya yaitu dengan diteguhkannya hati dalam bertindak untuk menjaga akidahnya.

Hal ini juga terjadi pada pemuda Ashhabul kahfi yang dimana mereka diteguhkan hatinya dalam menyampaikan kebenaran bahwa Allah Swt Tuhan satu-satunya. Hal ini difirmankan oleh Allah Swt pada Q.S Al-Kahfi ayat 14, yaitu :

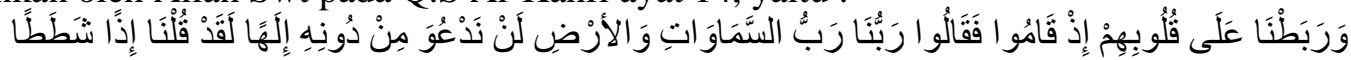

"Dan Kami teguhkan hati mereka ketika mereka berdiri, lalu mereka berkata, "Tuhan kami adalah Tuhan langit dan bumi; Kami tidak menyeru tuhan selain Dia. Sungguh, kalau kami berbuat demikian tentu kami telah mengucapkan perkataan yang sangat jauh dari kebenaran.”

Para mufassir menafsirkan ayat ini bahwa, mereka Ashhabul kahfi yang dikenal sebagai pemuda, Allah teguhkan keimanan mereka karena mereka telah berusaha untuk menjaga akidah mereka dari fitnah penguasa pada saat itu, dan karena hal itu Allah berikan petunjuk dan penguatan terhadap akidah mereka supaya para pemuda tersebut meninggalkan harta benda dan kehidupan di negaranya.

Allah Swt bahkan memberikan kecukupan terhadap para pemuda yang Allah berikan pentujuk untuk berdiam di sebuah gua dan Allah Swt berikan mereka tidur yang nyenyak dan menjaganya saat penguasa dan jajarannya mencari para pemuda tersebut.

Dari hal tersebut dapat dipahami bahwa ketika seorang hamba yang bahkan tergolong masih pemuda pada usianya dapat menjaga akidahnya dengan pertolongan Allah Swt. Karena dalam menjaga akidah tidak terpaku dalam usia, bahkan disampaikan oleh Ismail Ibnu Katsir dalam tafsirnya bahwa mereka itu adalah segolongan kaum muda yang lebih siap dalam menerima kebenaran dan petunjuk daripada para pendahulu mereka yang sombong dan tenggelam dalam kebathilan.

Hal ini selaras dengan pendapat menurut Umar Sulaiman Al-Asyqar, (2017 : 1) bahwa Akidah adalah perkara - perkara yang dibenarkan oleh jiwa, yang menjadikan hati tenang, serta menjadi keyakinan si pemiliknya. Tidak sedikit pun tercampur keraguan dan kebimbangan.

Sejalan juga dengan pendapat dari Ahmad Zakaria Anshori (rpail, 2015 : 9) bahwa dari tujuan Akidah Islam diantaranya, adalah: 
1. Memelihara manusia dari kemusyrikan

Mencegah manusia dari kemusyrikan perlu adanya pedoman yang jelas mengenai kepercayaan kepada Tuhan yang Maha Esa. Kemungkinan manusia jatuh terhadap kemusyrikan selalu terbuka, dengan mempelajari Akidah Islam, manusia dapat terpelihara dari perbuatan syirik.

2. Menghindarkan diri dari pengaruh akal pikiran yang menyesatkan

Manusia diberi kelebihan oleh Allah Swt daripada makhluk lain yaitu berupa akal pikiran. Pendapat atau paham yang sebatas didasarkan melalui akal manusia terkadang dapat menyesatkan manusia itu sendiri. Karena hal tersebut akal perlu dibimbing oleh Akidah Islam supaya manusia dapat terhindar dari kehidupan yang menyesatkan.

Pertolongan Allah akan hadir setelah berupaya dalam menjaga akidah Islam, sebagaimana yang disampaikan oleh Awang surya (2017 : 123) bahwa sebuah sikap yang merupakan manifestasi dari kepercayaan yang teguh dan prasangka baik kepada Allah maka akan hadir perasaan tenang di hatinya.

Dari teori-teori diatas dapat disimpulkan bahwa Ketika keimanan yang dijaga dari fitnah atau hal-hal yang dapat merusak akidah dan meminta pertolongan kepada Allah, maka Allah Swt akan memberikan keteguhan hati dan penguatan terhadap akidahnya dan Allah akan jaga mereka yang menjaga akidahnya bahkan jika mereka adalah seorang pemuda sekalipun.

\section{Pemuda yang ingin menjaga akidahnya dari fitnah, maka harus diiringi dengan ikhtiyar yang sesuai dengan syari'at Islam.}

Ketika pemuda sudah berupaya dalam berdo'a dan menyampaikan kebenaran kepada kaumnya sebagai bentuk upaya penjagaan akidahnya, dan hal tersebut sudah tidak dapat berdampak akan meniadakan fitnah yang dapat merusak akidah itu, maka perlu adanya ikhtiar berupa hijrah dari daerah tersebut, sebagaimana pemuda Ashhabul kahfi ketika pertolongan Allah turun berupa diteguhkannya hati para pemuda tersebut untuk berhijrah meninggalkan kaumnya dan bersembunyi di dalam gua. Allah sampaikan dalam QS Al-Kahfi, ayat 16, yaitu :

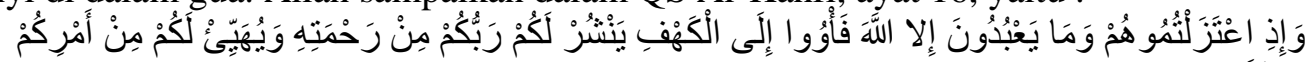

"Dan apabila kamu meninggalkan mereka dan apa yang mereka sembah selain Allah, maka carilah tempat berlindung ke dalam gua itu, niscaya Tuhanmu akan melimpahkan sebagian rahmat-Nya kepadamu dan menyediakan sesuatu yang berguna bagimu dalam urusanтu."

Para mufassir menafsirkan ayat ini, bahwa mereka berikhtiar dengan menanyakan alasan yang jelas dapat diterima oleh hati dan pikiran akan penyembahan mereka kepada selain Allah Swt. Dan ketika mereka penguasa dan rakyatnya yang tidak dapat memberikan alas an yang jelas dan tetap zalim, maka para pemuda itu tetap berikhtiar dengan menyampaikan kebenaran tentang Akidah yang benar, yang menyembah Tuhan yang menguasai langit dan bumi yaitu Allah Swt.

Dari pendapat para ahli tafsir, dapat disimpulkan bahwa ketika butuh akan dijaganya sebuah akidah maka perlu adanya ikhtiar terlebih dahulu. Dengan hal itu maka pertolongan Allah akan muncul secara tidak langsung maupun secara langsung, salah satunya akidahnya akan menguat.

Sebelum hadirnya akidah yang menguat, maka akan diperlukannya ikhtiar berupa pendidikan akidah, supaya disaat anak beranjak menjadi seorang pemuda pemahamannya kuat atau tidaknya tentang akidah akan berkesinambungan dengan penanaman pendidikan yang diterimanya selama masa hidupnya.

Maka ada beberapa metode yang dikemukakan oleh Abdullah Nashih 'Ulwan

1. Membuka Kehidupan Anak Dengan Kalimat Laa Ilaaha Illalaah

Sebagaimana yang diriwayatkan oleh Al-Hakim dari Ibnu Abbas ra, bahwa Nabi Saw bersabda :

"Bukakanlah untuk anak-anak kalian pertama kalinya dengan kalimat la illaha illallah (Tiada sesembahan yang hak kecuali Allah). 
Faedah dari perintah ini adalah agar kalimat tauhid itu dan syiar masuknya seseorang ke dalam agama Islam menjadi yang pertama kali didengar, diucapkan, dan lafal yang pertama kali diingat oleh anak. Pada pembahasan terdahulu, yaitu Ahkamul Maulud (hukum-hukum seputar kelahiran), dijelaskan tentang sunnahnya mengumandangkan azan pada telinga kanan anak dan mengiqamahnya pada telinga kirinya. Tidak diragukan lagi bahwa perbuatan ini memiliki pengaruh yang besar di dalam mengajarkan anak dasar akidah dan prinsip tauhid dan keimanan.

2. Mengenalkan Hukum-hukum Halal dan Haram Kepada Anak Sejak Dini Sebagaimana yang diriwayatkan oleh Ibnu Jarir dan Ibnu Al-Mundzir dari hadits Ibnu Abbas ra bahwa beliau berkata :

“Ajarkanlah mereka untuk taat kepada Allah dan takut berbuat maksiat kepada-Nya, serta suruhlah anak-anak kamu untuk menaati perintah-perintah dan menjauhi laranganlarangan. Karena, hal itu akan memelihara mereka dan kamu dari api neraka."

Faedah dari perintah ini adalah agar seorang anak Ketika membuka kedua mata dan tumbuh besar, ia telah mengetahui perintah-perintah Allah sehingga ia bersegera melaksanakannya. Ia juga mengenal larangan-larangan Allah sehingga bersegera melaksanakannya. Ia juga mengenal larangan-larangan Allah sehingga bersegera menjauhinya. Dan saat anak sudah semakin paham akan hukum-hukum halal dan haram dan semakin terikat sejak dini dengan hukum-hukum syariat, makai a akan mengenal Islam sebagai hukum dan konsep.

3. Menyuruh Anak Untuk Beribadah Ketika Telah Memasuki Usia Tujuh Tahun Sebagaimana yang diriwayatkan oleh Al-Hakim dan Abu Dawud dari hadits Ibnu Amru bin Al-Ash ra bahwa Rasulullah Saw bersabda :

"Perintahkan anak-anak kamu melaksanakan shalat pada usia tujuh tahun, dan di saat mereka telah berusia sepuluh tahun pukullah mereka jika tidak melaksanakannya, dan pisahkanlah tempat tidurnya."

Diqiyaskan sebagaimana perintah shalat, hendaknya juga membiasakan anak melakukan puasa jika dirasa anak telah mampu, dan haji jika orang tuanya mampu.

Faedah perintah ini adalah agar anak mau mempelajari hukum-hukum ibadah ini sejak tumbuh dewasanya serta akan terbiasa melaksanakan dan menegakkannya. Selain itu juga agar ia terdidik untuk taat kepada Allah, melaksanakan hak-Nya, bersyukur kepadaNya, Kembali kepada-Nya, berpegang teguh kepada-Nya, bersandar kepada-Nya, dan berserah diri kepada-Nya. Di samping itu, agar dengan ibadah ini anak-anak bisa terjaga kesucian rohaninya, Kesehatan fisiknya, kebaikan akhlaknya, serta lurusnya perkataan dan perbuatannya.

4. Mendidik Anak Untuk Mencintai Rasul, Keluarganya, dan Membaca Al-Qur'an Sebagaimana yang diriwayatkan oleh Ath-thabrani dari Ali bin Abi Thalib ra bahwa Nabi Saw bersabda :

"Didiklah anak-anak kamu atas tiga hal, mencintai Nabi kamu, mencintai ahli baitnya, dan membaca Al-Qur'an, karena orang yang mengamalkan Al-Qur'an nanti akan mendapat naungan Allah pada hari Ketika tidak ada naungan kecuali dari-Nya Bersama para nabi dan orang-orang yang suci."

Yang berkaitan dengan hal ini juga mengajari seni berperang Rasulullah, perjalanan hidup para shahabat, karakteristik para pemimpin agung (dalam sejarah), dan peperangan-peperangan dahsyat yang terjadi di sepanjang sejarah.

Faedah dari perintah ini adalah agar anak mau meneladani perjalanan hidup para pendahulu, baik pergerakannya, kepahlawanannya, maupun peperangan-nya. Dan agar anak semakin terikat dengan sejarah, baik perasaan, kejayaan, maupun kebanggaan mereka. Selain itu juga agar anak semakin terikat dengan Al-Qur'an Al-Karim, baik rohani, kosep, maupun bacaannya.

Berikut ini adalah perkataan para ulama perihal masalah pendidikan akan wajibnya menuntun anak untuk membaca Al-Qur'an, mempelajari sejarah peperangan Rasulullah, dan sejarah para pahlawan. 
1. Sa'ad bin Abi Waqqash 2 berkata, "Kami mengajari anak-anak kami tentang sejarah peperangan Rasulullah sebagaimana kami mengajari mereka surat Al-Qur'an"

2. Imam Al-Ghazali berpesan di dalam bukunya lhya' Ulumiddin, "(Yaitu) dengan mengajari anak Al-Qur'an Al-Karim, hadits-hadits, kisah orang-orang baik, kemudian beberapa hukum agama."

3. Ibnu Khaldun di dalam Muqaddimah-nya memberikan arahan tentang pentingnya mengajarkan dan menghafalkan Al-Qur'an pada anak. Beliau menjelaskan bahwa mengajari Al-Qur'an kepada anak adalah fondasi awal untuk mempelajari semua metode pembelajaran yang ada di berbagai negara Islam, karena ia adalah syiar agama yang bisa mengokohkan akidah dan menancapkan keimanan.

4. Ibnu Sina menasihatkan di dalam kitabnya As-Siyasah agar seorang anak diajari AlQur'an sejak dini, di samping menyiapkan pengajaran fisik dan akal. Hal ini bertujuan supaya anak mampu menyerap bahasa Al-Qur'an dan tertanam di dalam dirinya ajaran keimanan.

5. Diriwayatkan di dalam banyak buku sejarah dan sastra bahwa Fadhl bin Zaid pernah melihat anak laki-laki seorang wanita Arab dan la sangat mengaguminya. Wanita itu bercerita cara mendidik anaknya, "Ketika ia sudah berumur lima tahun, aku menyerahkannya kepada seorang pendidik. Pendidik itu mengajari membaca dan menghafal AI-Qur'an, syair, serta meriwayatkannya. la juga dihibur dengan kejayaan kaumnya serta diajari meneladani perbuatan terpuji bapak dan kekeknya. Setelah ia memasuki masa remaja, maka aku mengajaknya naik ke punggung kuda agar ia berlatih menjadi penunggang kuda, memanggul senjata, berkelana ke berbagai wilayah, dan mau mendengarkan perintah."

Dari teori Abdullah Nashih Ulwan dapat dijadikan pedoman dalam mendidik anak karena keseluruhan landasan pendidikan akidahnya berlandaskan petunjuk dan wasiat Rasulullah Saw.

Beberapa Implikasi yang terdapat dalam Qs Al-Kahfi : 10-16 diantaranya :

1. Seorang pemuda muslim harus diberi pemahaman bahwa perlu menjaga akidahnya dari segala hal yang dapat merusak akidahnya, karena hal tersebut adalah perintah Allah Swt. dan supaya terhindarnya dari pemikiran yang sesat atau menyimpang itu perlu upaya dari pendidik maupun pemudanya, salah satunya yaitu berdo'a kepada-Nya.

2. Seorang pendidik hendaknya menanamkan Pendidikan akidah kepada pemuda dimulai dengan memberikan pemahaman tentang tauhid, supaya tertanam kecintaan dan merasa diawasi oleh Allah Swt Ketika hal tersebut kuat pemahamannya maka akan teguh keimanannya.

3. Orang tua dan guru sebagai pendidik hendaknya membuat kerja sama dan pembiasaan beramal sholeh di lingkungan masjid, sekolah, dan rumah dalam upaya menanamkan pendidikan aqidah pada pemuda.

4. Karena pemahaman akan akidah dibangun dari Penanaman Pendidikan Akidah Islam dan hal ini juga merupakan ikhtiar yang diajarkan oleh Rasulullah Saw maka penting menanamkan Pendidikan akidah pada pemuda supaya kuat dalam menjaga akidahnya tetap pada koridor Akidah Islam.

5. Allah akan memberikan pertolongan yang lapang kepada seorang muslim yang butuh akan keterjagaan Akidah Islamnya jika seseorang muslim khususnya pemuda, berikhtiar terlebih dahulu untuk menjaga Akidah Islamnya tetap pada koridor yang benar dan sesuai dengan ajaran Islam.

\section{Kesimpulan}

1. Pendapat para mufasir tentang Al-Qur'an surat Al-Kahfi ayat 10-16

Pemuda Ashhabul kahfi, mereka merupakan para pemuda yang lebih siap menerima kebenaran dan petunjuk daripada para pendahulu mereka yang sombong dan tenggelam dalam kebathilan. Oleh karenanya, kebanyakan orang-orang yang menerima seruan Rasulullah Saw adalah dari kalangan pemuda. Ketika pemuda Ashhabul Kahfi meninggalkan tempat tinggal dan harta bendanya untuk menjaga akidahnya yang benar, 
maka mereka berdo'a kepada Allah Swt, lalu Allah Swt berikan kelapangan RahmatNya, bahkan mereka diberi petunjuk untuk berlindung di dalam gua dan mencukupi seluruh kebutuhan pemuda Ashhabul kahfi. Allah Swt jaga mereka dengan diberikannya tidur yang nyenyak sampai bertahun-tahun lamanya setelah mereka melakukan banyak ikhtiar untuk menyelamatkan akidah mereka. Lalu Allah bangunkan mereka sebagai petunjuk dan bentuk Allah Maha Kuasa.

2. Esensi dari Al-Qur'an surat Al-Kahfi ayat 10-16

a. Seorang pemuda harus kuat dalam menjaga keimanannya dari fitnah yang dapat merusak akidah.

b. Allah akan memberikan pertolongan dalam bentuk apapun yang tidak pernah terduga kepada seorang yang imannya teguh kepada Allah.

c. Pemuda yang ingin menjaga akidahnya dari fitnah, maka harus diiringi dengan ikhtiyar yang sesuai dengan syari'at Islam.

3. Pendapat ahli mengenai upaya menanamkan Pendidikan akidah pada pemuda

Akidah Islam merupakan ikatan keyakinan pada seseorang tentang konsepsi Ketuhanan Yang Maha Esa yang dibenarkan oleh jiwa tanpa keraguan dan kebimbangan. Isi pokok dari Akidah Islam adalah tentang keimanan yang wajib diyakini oleh setiap Muslim atau disebut juga rukun iman.

Akidah Islam harus ditanamkan pada pemuda khususnya dengan cara yang telah Rasulullah Saw wasiatkan, yaitu :

1. Membuka kehidupan dengan kalimat Laa Ilaaha Illalaah,

2. Mengenalkan hukum-hukum halal dan haram,

3. Menyuruhnya untuk beribadah ketika telah memasuki usia pemuda,

4. Mendidiknya untuk mencintai rasul, keluarganya, dan membaca Al-Qur'an.

4. Implikasi dari Al-Qur'an surat Al-Kahfi ayat 10-16

1. Seorang pemuda muslim harus diberi pemahaman bahwa perlu menjaga akidahnya dari segala hal yang dapat merusak akidahnya, karena hal tersebut adalah perintah Allah Swt. dan supaya terhindarnya dari pemikiran yang sesat atau menyimpang itu perlu upaya dari pendidik maupun pemudanya, salah satunya yaitu berdo'a kepada-Nya.

2. Seorang pendidik hendaknya menanamkan Pendidikan akidah kepada pemuda dimulai dengan memberikan pemahaman tentang tauhid, supaya tertanam kecintaan dan merasa diawasi oleh Allah Swt Ketika hal tersebut kuat pemahamannya maka akan teguh keimanannya.

3. Orang tua dan guru sebagai pendidik hendaknya membuat kerja sama dan pembiasaan beramal sholeh di lingkungan masjid, sekolah, dan rumah dalam upaya menanamkan pendidikan aqidah pada pemuda.

4. Karena pemahaman akan akidah dibangun dari Penanaman Pendidikan Akidah Islam dan hal ini juga merupakan ikhtiar yang diajarkan oleh Rasulullah Saw maka penting menanamkan Pendidikan akidah pada pemuda supaya kuat dalam menjaga akidahnya tetap pada koridor Akidah Islam.

5. Allah akan memberikan pertolongan yang lapang kepada seorang muslim yang butuh akan keterjagaan Akidah Islamnya jika seseorang muslim khususnya pemuda, berikhtiar terlebih dahulu untuk menjaga Akidah Islamnya tetap pada koridor yang benar dan sesuai dengan ajaran Islam.

\section{Acknowledge}

Alhamdulillahirobbil'alamin, puji dan syukur kepada Allah Swt, dengan izin Allah Swt berakhirnya kesimpulan dan saran, maka berakhir juga penyusunan skripsi ini dengan judul "Implikasi Al-Quran Surat Al-Kahfi Ayat 10-16 Tentang Kisah Ketangguhan Iman Pemuda Ashhabul Kahfi Terhadap Upaya Menanamkan Pendidikan Akidah", untuk memenuhi tugas akhir dan sebagai syarat meraih gelar Sarjana Pendidikan Islam (S.Pd) pada program studi Agama Islam Fakultas Tarbiyah dan Keguruan Universitas Islam Bandung. 
Penulis menyadari masih banyak kekurangan dan jauh dari kata sempurna dalam penyusunan skripsi ini. Tetapi dengan kekurangan ini penulis berharap kepada Allah Swt akan skripsi ini dapat memberikan manfaat bagi penulis khususnya dan sumbangan pemikiran yang berharga dari penulis untuk para pendidik.

Akhir kata, terima kasih kepada semua pihak yang telah membantu penulis dalam penyusunan skripsi ini.

\section{Daftar Pustaka}

[1] Al-Qur'an Al-Karim

[2] Abidin, Z. (2021). Tafsir Al-Misbah dan Al-Maraghi Tentang Nilai-nilai Pendidikan yang terkandung dalam surat Al-Kahfi ayat 66-70. SALIHA, 4, 20-36.

[3] Ahmad Munawwar, K. A. (2016). Akidah dan Akhlak dalam Pendidikan Islam. Johor Bahru: Universiti Teknologi Malaysia.

[4] Anang. (2016). Nilai-Nilai pendidikan dalam kisah ashabul kahfi (Telaah qur'an surat Alkahfi ayat 9-26). Jakarta.

[5] An-Nahlawi, A. (1995). Pendidikan Islam di Rumah, Sekolah, Masyarakat . Jakarta: Gema Insani Press.

[6] Ar-Ramadi, A. (2017). Menanamkan Iman Kepada Anak. Jakarta Timur: Istanbul.

[7] Azis, Rosmiaty. (2019). Ilmu Pendidikan Islam (II ed.). Gowa: SIBUKU.

[8] Cindriani, W. (2017). Implikasi Dari Al-Qur'an Surat Ibrahim Ayat 24-26 Tentang Metode Perumpamaan Terhadap Pembelajaran Aqidah. Bandung: Universitas Islam Bandung.

[9] Dedi Wahyudi, N. (2017). Pengantar Aqidah Akhlak dan Pembelajarannya. Yogyakarta: Lintang Rasi Aksara Books.

[10] Fahrur, Abu Faris (2017). Belajar Islam untuk Pemula. Solo: Aqwam Media Profetika.

[11] Hayati, Rosiah. (2020). Analisis Q.S. Al-Kahfi Ayat 27-31 Dalam Perspektif Pendidikan Islam. Lampung: UIN Intan Lampung.

[12] Hamid, A. (2005). Panduan Aqidah Lengkap. Bogor: Pustaka Ibnu Katsir.

[13] Herman, D. (2016). Penanaman Nilai-Nilai Pendiidkan Karakter Dalam Pembelajaran Muatan Lokal Melalui Kitab Muntakhobat Fil Mahfudzot di SDIT Al-Kautsar Jepang Mejobo Kudus. Kudus: Sekolah Tinggi Agama Islam Negeri Kudus.

[14] Hidayat, R. (2018). Strategi Guru Pendidikan Agama Islam Dalam Pembinaan Akhlakul Karimah Siswa Sekolah Menengah Pertama Negeri 1 Bergas Kabupaten Semarang Tahun Pelajaran 2018/2019. Semarang: IAIN Salatiga.

[15] Ibnuansyah, Rahmat. (2017). Kisah Ashhab AL-Kahfi dalam Al-Qur'an (Studi Komparatif antar tafsir ibnu katsir dengan tafsir al maraghi). Lampung.

[16] Istiqomah, S. (2021). Kisah Ashabul Kahfi Dalam Al-Qur'an (Studi Komparatif tafsir almisbah dengan tafsir ibnu katsir). Ponorogo: IAIN Ponorogo.

[17] Jalaludin. (2016). Psikologi Agama. Depok: Rajagrafindo Persada.

[18] Mohd Radhi. (2012). Akidah Islam . Seremban: Universiti Sains Islam Malaysia.

[19] Pupuh Faturrohman, S. S. (2011). Strategi Belajar Mengajar Melalui Penanaman Konsep Umum dan Islam. Bandung: Refika Aditama.

[20] Riadi, Marwan. (2018). Nilai-Nilai Pendidikan Akidah Dalam Surat Al-Kahfi . Medan: UINSU Medan.

[21] Rahmansyah. (2020). Nilai-Nilai Pendidikan Islam Dalam Kisah Aṣhābul Kahfi. Medan: Universitas Islam Negeri Sumatera Utara.

[22] Saputri. (2016). Implikasi Pendidikan Dari Konsep Al-Baghyu dalam Al-Quran Terhadap Interaksi Sosial (Studi terhadap QS An-Nahl: 90 dan Al-A'raf: 33). Bandung: Universitas Islam Bandung.

[23] Sundari. (2018). Konsep Sabar Dalam Surat Al-Kahfi dan Implikasinya dalam Pendidikan Islam (Kajian Tafsir Ibnu Katsir). Curup: IAIN Curup. 
136 | Muhammad Dwieky Cahyadien, et al.

[24] Surya, A. (2017). Berjuta Jalan Menggapai Pertolongan Allah. Bogor: Elex Media Komputindo.

[25] Taopikurohman, O. (2018). Nilai-Nilai Pendidikan Islam Menurut Al-Qur'an Surat Al-Kahfi Ayat 60-82 (Kajian Tafsir Al-Misbah Dan Tafsir Al-Maraghi). OASIS : Jurnal Ilmiah Kajian Islam, 2, 28-40.

[26] Ulfarida, L. (2021). Pengelolaan Program Bina Pribadi Islam dalam upaya menanamkan kecerdasan spiritual peserta didik di SMP IT Al-Uswah Surabaya. Surabaya: IAIN Sunan Ampel Surabaya.

[27] 'Ulwan, A. N. (2020). Tarbiyatul Aulad Fil Islam. Solo: Insan Kamil. 